\title{
POPULAR MARKETS:
}

\section{FROM FUTURE STUDIES TO THE DEVELOPMENT OF PRODUCTS}

\author{
James Terence Coulter Wright \\ Professor - Postgraduate Business Administration Program \\ University of São Paulo - USP, Brazil \\ jameswright@fia.com.br
}

Antonio Thiago Benedete da Silva

Master's Degree Candidate - Postgraduate Business Administration Program University of São Paulo - USP, Brazil

atbenedete@usp.br

Renata Giovinazzo Spers

Professor - Postgraduate Business Administration Program

Fundação Instituto de Administração - FIA, Brazil

renatag@fia.com.br

\section{ABSTRACT}

Strategies for running companies in low-income markets have been in the spotlight in both the academic and the corporate environments. However, the first discussions about the relevance of such markets arose during the 1980s, when scenario-prospecting studies showed that popular markets would provide many opportunities around the year 2000. Indeed, at present, the base of the pyramid has many unaddressed needs that offer business possibilities for those companies that are willing to review their strategies. In this context, product development becomes increasingly important, since products targeting consumers of the $C, D$ and $E$ classes may need different features from those of goods manufactured for the $A$ and $B$ classes. The aim of this study is to revisit past popular market forecasts and to identify development trends for goods that target lowincome consumers. Our results indicate that Wright and Johnson's (1984) studies predicted that Brazil would maintain both qualitative and quantitative progress in its socioeconomic development over the next two decades and that the development of popular products is undergoing a buoyant phase. Several functional perspectives were used to develop an understanding of the phenomenon, especially marketing, engineering and manufacturing.

Key words: Future studies. Popular markets. Product development. 


\section{MERCADOS POPULARES:}

\section{DOS ESTUDOS DO FUTURO AO DESENVOLVIMENTO DE PRODUTOS}

\section{RESUMO}

As estratégias de atuação das empresas em mercados de baixa renda têm sido assunto de destaque no meio acadêmico e empresarial. Contudo, as primeiras discussões sobre a importância desses mercados surgiram na década de 80 , quando estudos de prospecção de cenários indicavam que os mercados populares ofereceriam inúmeras oportunidades por volta do ano 2000. De fato, atualmente, a base da pirâmide apresenta algumas demandas não atendidas que se consubstanciam em possibilidades de negócios para as empresas dispostas a rever suas estratégias. Nesse contexto, ganha importância o processo de desenvolvimento de produtos, uma vez que os bens destinados a consumidores das classes $C, D$ e $E$ podem requerer características diferentes dos produzidos para as classes $A$ e B. Neste trabalho, objetivou-se resgatar o histórico da prospectiva para mercados populares e identificar tendências de desenvolvimento de produtos para consumidores de baixa renda. Constatou-se que o trabalho de Wright e Johnson (1984) prospectava que o Brasil manteria um avanço qualitativo e quantitativo do seu desenvolvimento socioeconômico nas duas décadas seguintes, e que o desenvolvimento de produtos populares encontra-se em plena fase de ebulição, sendo utilizadas diversas perspectivas funcionais para seu estudo, em especial marketing, engenharia e manufatura.

Palavras-chave: Estudos do futuro. Mercados populares. Desenvolvimento de produtos. 


\section{INTRODUCTION}

In the 1980s, scenario-related prospecting studies for the year 2000 predicted that popular markets would offer countless opportunities to be explored. This prediction came true. Recent studies - on both the domestic and the international level - have shown the social and economic importance of lowincome markets, which generate value for companies and promote inclusive consumption for the lower-income segment of the population (Wright, 1993, 1994; Prahalad, 2005; World Resources Institute, 2007).

An analysis of the income growth of Brazilian families in the last few years reveals income distribution progress. The Gini Index, which measures income inequality on a scale from zero (perfect equality) to one (maximum inequality) has been dropping consistently. In 1995, the family Gini Index in Brazil stood at 0.599. By 2005, it was down to 0.566 and tending to drop by $1.2 \%$ a year (Barros et al., 2006). The income growth of this population segment allows it to become a stronger player in the generation of value through consumption.

Giovinazzo (2003), upon analyzing the gross revenue fluctuations from 1997 to 2001 of food, beverage, tobacco, personal care, home appliances and retail firms, found that, in Brazil, corporate revenues derived from the lowincome segment of the population enjoyed average real growth of $25 \%$ a year, whereas firms targeting the $A$ and $B$ classes suffered an average drop of $0.7 \%$ a year. Taking into account that GDP growth came to $1.71 \%$ a year during the period analyzed, the growth of companies that aim at the low-income markets is especially significant.

Traditionally, the big companies - capable of generating economies of scale and competitive business operations - have focused heavily on the highincome markets, gearing their strategies and competencies to a segment of consumers whose characteristics often differ substantially from those of lowincome consumers. Thus, the unmet needs at the base of the pyramid can provide business opportunities for companies willing to rethink the value chain and the product to be delivered to the consumer. 
This is the context of this paper, the objectives of which are to retrieve the history of popular markets' prospects and to identify development trends for products for low-income consumers. One must stress that product development is considered within a broad perspective, which encompasses the dimensions of a companies' overall strategies and the interactions among different business functions, such as manufacturing, engineering and technology.

\section{POPULAR MARKETS: EARLY ESTIMATES AND THE CURRENT MARKET}

In the field of studies about the future, estimates on the rise of the lowincome markets can be found in a number of scenarios related to the telecom industry in Brazil in the 2000s, prepared by the researchers Wright and Johnson (1984). According to them, the basic objective of prospecting studies is to establish a scenario framework that will allow the firm to make strategic decisions based on an explicit analysis of the planning assumptions, thus highlighting the opportunities for new business development. In the aforementioned study, Wright and Johnson (1984) emphasize the systematic analysis of the process of socioeconomic changes with regard to technological innovations. The reason for this is that the complexity of social futures dictates focusing on attitudes and values that are already shared within a given sociocultural context, or on attitudes and values that are emerging and that have a stronger influence on economic and social development models (Wright and Johnson, 1984).

In their scenarios, Wright and Johnson (1984) predicted that during the subsequent two decades, Brazil would maintain the qualitative and quantitative progress of its social and economic development, encompassing income growth and improved income distribution, in line with the values of a more egalitarian society. According to them, as the buying power of this enormous contingent of consumers increased, new market opportunities would arise, given that firms were then focusing on the middle and high-income markets, which they continue to do to this day.

According to the World Resources Institute (2007), the world's lowincome population represents a US\$5 trillion market and comprises some 4 billion people, most of whom live in Asia (2,86 billion), followed by Africa, (486 
million), Latin America (360 million) and Eastern Europe (254 million). However, when consumption power is valued in dollar terms, the market weights change. In the ensuing scenario, Asia (US\$3.4 trillion) continues to stand out, followed by Latin America (US\$509 billion), Eastern Europe (US\$458 billion) and Africa (US\$429 billion). One must point out that the African and Asian markets are predominantly located in rural areas, whereas those in Latin America and the Caribbean are mainly urban.

The consumption pattern of consumers at the base of the pyramid centers on meeting their basic needs. Thus, the food industry, followed by the energy, housing and transportation industries, captures most of their income. According to data from Pesquisa Nacional de Amostra por Domicílios 2006/ PNAD (National Survey by Household Sampling), $89 \%$ of all Brazilian families are in the low-income population segment (IBGE, 2006), which accounts for a significant share of the domestic market. The consumption patterns of the Brazilian market - summarized in Table 1 - are similar to those of other markets around the world.

\section{Table 1: Summary of the expense-related percentages and size of the main market segments that account for the bulk of expenditures of Brazilian families at the base of the pyramid}

\begin{tabular}{|c|c|c|}
\hline RANGE & Main Budget Allocations & $\begin{array}{l}\text { Size OF the MARKet IN THE } \\
\text { Major Sectors }\end{array}$ \\
\hline Range 1 : up to 2 minimum salaries & $\begin{array}{l}\text { Housing }=37.2 \% \\
\text { Food }=32.7 \% \\
\text { Transportation }=8.2 \% \\
\text { Clothing }=5.3 \% \\
\text { Health care }=4.1 \%\end{array}$ & $\begin{array}{l}\mathrm{R} \$ 46.2 \text { billion } \\
\mathrm{R} \$ 40.7 \text { billion } \\
\mathrm{R} \$ 10.1 \text { billion } \\
\mathrm{R} \$ 06.6 \text { billion } \\
\mathrm{R} \$ 05.1 \text { billion }\end{array}$ \\
\hline $\begin{array}{l}\text { Range } 2 \text { : from } 2 \text { to } 3 \text { minimum } \\
\text { salaries }\end{array}$ & $\begin{array}{l}\text { Housing }=36.8 \% \\
\text { Food }=29.8 \% \\
\text { Transportation }=8,6 \% \\
\text { Clothing }=5.7 \% \\
\text { Health care }=4.7 \%\end{array}$ & $\begin{array}{l}\mathrm{R} \$ 39.0 \text { billion } \\
\mathrm{R} \$ 31.5 \text { billion } \\
\mathrm{R} \$ 09.1 \text { billion } \\
\mathrm{R} \$ 06.0 \text { billion } \\
\mathrm{R} \$ 04.9 \text { billion }\end{array}$ \\
\hline $\begin{array}{l}\text { Range 3: from } 3 \text { to } 5 \text { minimum } \\
\text { salaries }\end{array}$ & $\begin{array}{l}\text { Housing }=35.9 \% \\
\text { Food }=25.4 \% \\
\text { Transportation }=10.9 \% \\
\text { Clothing }=5.8 \% \\
\text { Health care }=5.0 \%\end{array}$ & $\begin{array}{l}\mathrm{R} \$ 60.9 \text { billion } \\
\mathrm{R} \$ 43.2 \text { billion } \\
\mathrm{R} \$ 18.5 \text { billion } \\
\mathrm{R} \$ 09.8 \text { billion } \\
\mathrm{R} \$ 08.4 \text { billion }\end{array}$ \\
\hline $\begin{array}{l}\text { Range } 4 \text { : from } 5 \text { to } 10 \text { minimum } \\
\text { salaries }\end{array}$ & $\begin{array}{l}\text { Housing }=32.7 \% \\
\text { Food }=21 \% \\
\text { Transportation }=13.4 \% \\
\text { Clothing }=5.7 \% \\
\text { Health care }=5.2 \%\end{array}$ & $\begin{array}{l}\mathrm{R} \$ 81.1 \text { billion } \\
\mathrm{R} \$ 52.0 \text { billion } \\
\mathrm{R} \$ 33.2 \text { billion } \\
\mathrm{R} \$ 14.0 \text { billion } \\
\mathrm{R} \$ 13.0 \text { billion }\end{array}$ \\
\hline
\end{tabular}


Table 1 shows that, for example, families earning up to 2 minimum salaries a month allocate $83.3 \%$ of their budget to essential survival expenses, such as food, housing, clothing and transportation. Food accounts for $32.7 \%$ of their spending, housing for $32.7 \%$, transportation for $8.2 \%$, and clothing for $5.3 \%$.

According to data from the latest PNAD (National Survey by Household Sampling), conducted in 2006 by IBGE (the Brazilian Geography and Statistics Institute), Brazil has a contingent of approximately 58 million families. An analysis of the average income of these consumption units shows that income is still highly concentrated in Brazil; in other words, $41.3 \%$ of the families earn an average monthly income of 2 minimum salaries or less, while $2.7 \%$ of the families earn more than 20 minimum salaries.

Chart 1 shows the evolution of the income range of Brazilian families from 1995 to 2006. One must point out the reduction of extreme poverty and an increase in the percentage of families with very low income moving upwards, toward the lower middle class.

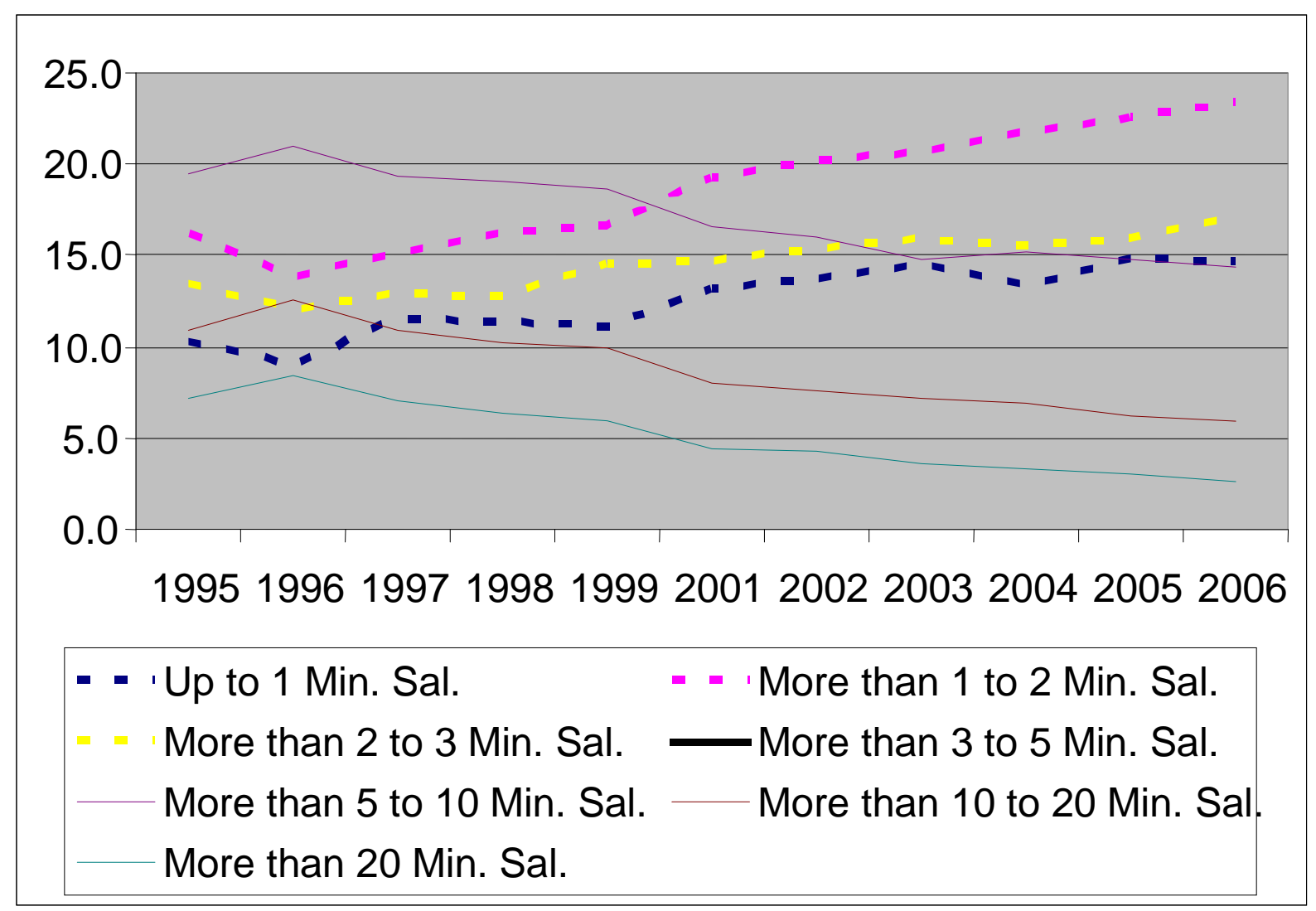

Chart 1: Evolution of the number of Brazilian families by income range. 
Although income inequality is a historical characteristic of Brazil, the Gini Index, a measure of income inequality value of which ranges from zero (perfect equality) to one (maximum inequality), shows that the country has improved in this respect in the last few years. In 1995, Brazil's Gini Index stood at 0.599. By 2005 , this was down to 0.566 , and tending to drop by $1.2 \%$ a year (Paes de Barros et al, 2006). This population segment's income growth has enabled it to participate more vigorously in the generation of value via consumption.

\section{PRODUCT DEVELOPMENT}

Takahashi and Takahashi (2007) emphasize that new product development can be viewed as a journey from the abstract and the intangible, which contemplates subjective and still unclear ideas, to the real, the tangible, the result. This process seeks to transform objectives, intentions and ideas into something real, i.e., into products or solutions for which consumers will pay to satisfy their needs.

Slack, Chambers and Johnston (2007) emphasize three aspects of products and services: concept, bundle and process. The concept refers to the set of expected benefits, i.e., the global intent underlying the product or service from the consumer's point of view. The product bundle is the set of the components that provide the benefits defined in the concept. Some of these are essential for the purchase and cannot be eliminated without destroying the nature of the bundle, while others are used to improve the essential part, and are referred to as supporting goods and services. The process defines the relation between the components, making it possible for given products or services to perform their functions and deliver the concept's original objective.

Takahashi and Takahashi (2007) propose five steps for the product development process, as follows: generating the concept, planning the product, detailing the product, detailing the process, review and tests. The five steps are summarized below. 
$\checkmark$ Generating the concept (or conception): this consists of determining the characteristics of the product from the consumer's point of view. It is based on the identification of a need that is often perceived unclearly in the midst of the various situations involving the market. Therefore, one must conduct a careful analysis of the social trends, individual tastes and potential market, among other elements, to define precisely the real needs that the product is to satisfy.

$\checkmark$ Planning the product: this concerns translating the product concept into detailed specifications, including style, arrangement, specifications, cost, investment and technical choices. Though still intangible, the specifications created in this phase provide the first opportunity to interpret the product concept physically. In the authors' opinion, the two biggest challenges during this phase are to achieve external consistency, making the plan, the concept and the product compatible; and to achieve internal consistency, making the specifications, components, style and arrangement compatible.

$\checkmark$ Detailing the product: here, the product is decomposed into its components for detailed design and is then stored in the form of drawings. These are converted into prototypes that are tested until they are officially approved.

$\checkmark$ Detailing the process: the design of the product is detailed into process designs compatible with the current manufacturing processes.

$\checkmark$ Review and tests: the process-related information is converted into production factors and tested in the form of pilot batches in order to identify weak points or failures, which must be remedied before the product is launched for end consumers.

When a new product development (NPD) process is initiated, the project team must clearly understand the strategic direction of the business and its critical functions. The basis for NPD is the integration between functional and corporate strategies (Clark and Wheelwright, 1993). This can be achieved by means of a process that maps the strategies in each area, with emphasis on marketing, engineering and manufacturing. As Chart 1 shows, competition issues are analyzed by means of specific measures for each functional area. 


\begin{tabular}{|l|l|}
\hline \multicolumn{1}{|c|}{ FUNCTIONAL AREA } & \multicolumn{1}{|c|}{ SPECIFIC CONCEPTS AND MEASURES } \\
\hline Marketing & \multicolumn{1}{|c|}{$\begin{array}{l}\text { Product attributes (placed on a performance scale, and } \\
\text { indication of the importance that the consumer ascribes to the } \\
\text { attribute); position in relation to competitors. }\end{array}$} \\
\hline Distribution channels & Sales per channel; market share per channel. \\
\hline Generating the product & $\begin{array}{l}\text { Timing of new products; life cycle of models; the product's } \\
\text { relation relative to other products. }\end{array}$ \\
\hline Engineering & $\begin{array}{l}\text { Composition of employees' skills for the design, development } \\
\text { and engineering of products and processes. For example, } \\
\text { knowledge of mechanics, electronics, ergonomics, acoustics, } \\
\text { etc. }\end{array}$ \\
\hline Critical skills & $\begin{array}{l}\text { Range of the possible performance combinations of possibly } \\
\text { conflicting dimensions. }\end{array}$ \\
\hline Performance Trade-offs & $\begin{array}{l}\text { Performance of the critical components using different } \\
\text { technologies. }\end{array}$ \\
\hline Technology of the component \\
\hline Manufacturing & $\begin{array}{l}\text { Level of automation; fraction of output in different kinds of } \\
\text { processes. }\end{array}$ \\
\hline Process Technology & Role of suppliers; internal operations per components. \\
\hline Vertical integration & \begin{tabular}{l} 
Cost per volume levels; cost per production factor. \\
\hline Cost structure
\end{tabular} \\
\hline
\end{tabular}

\section{Chart 1: NPD and functional areas}

Source: Clark and Wheelwright (1993)

In this respect, Krishnan and Ulrich (2001) emphasize that research in product development is circumscribed by at least four perspectives - marketing, organizations, engineering and operations - which differ in terms of the level of abstraction at which they study the product development, moving from an aggregate level (organizations) to a more detailed one (engineering). Chart 2 shows further details regarding the different perspectives.

\begin{tabular}{|l|l|l|l|l|}
\hline & \multicolumn{1}{|c|}{ MARKETING } & \multicolumn{1}{|c|}{ ORGANIZATIONS } & \multicolumn{1}{|c|}{ ENGINERING } & \multicolumn{1}{c|}{ OPERATIONS } \\
\hline $\begin{array}{l}\text { Perspective } \\
\text { on the } \\
\text { product: }\end{array}$ & $\begin{array}{l}\text { A product is a } \\
\text { set of attributes. }\end{array}$ & $\begin{array}{l}\text { A product is an } \\
\text { artifact resulting } \\
\text { from an } \\
\text { organizational } \\
\text { process. }\end{array}$ & $\begin{array}{l}\text { A product is a } \\
\text { complex assembly } \\
\text { of interacting } \\
\text { components. }\end{array}$ & $\begin{array}{l}\text { A product is a } \\
\text { development } \\
\text { sequence and/or } \\
\text { steps of a } \\
\text { production } \\
\text { process. }\end{array}$ \\
\hline $\begin{array}{l}\text { Typical } \\
\text { performance } \\
\text { metrics: }\end{array}$ & $\begin{array}{l}\text { "Fit" with the } \\
\text { market, market } \\
\text { share, usefulness } \\
\text { to consumer } \\
\text { (sometimes } \\
\text { profit). }\end{array}$ & $\begin{array}{l}\text { Success of the } \\
\text { design. }\end{array}$ & $\begin{array}{l}\text { Form, function, } \\
\text { technical } \\
\text { performance, } \\
\text { innovation } \\
\text { (sometimes direct } \\
\text { costs). }\end{array}$ & $\begin{array}{l}\text { Efficiency, total } \\
\text { cost, service } \\
\text { level, lead-time, } \\
\text { use of capacity. }\end{array}$ \\
\hline
\end{tabular}

Continued 
Continuation

\begin{tabular}{|c|c|c|c|c|}
\hline & MARKETING & ORGANIZATIONS & ENGINEERING & OPERATIONS \\
\hline $\begin{array}{l}\text { Dominant } \\
\text { representative } \\
\text { paradigm }\end{array}$ & $\begin{array}{l}\text { Usefulness for } \\
\text { consumer as a } \\
\text { function of one } \\
\text { of the product's } \\
\text { attributes. }\end{array}$ & $\begin{array}{l}\text { There is no } \\
\text { dominant } \\
\text { paradigm. } \\
\text { Organizational } \\
\text { networks are } \\
\text { sometimes used. }\end{array}$ & $\begin{array}{l}\text { Geometric } \\
\text { models, technical } \\
\text { performance } \\
\text { parameter } \\
\text { models. }\end{array}$ & $\begin{array}{l}\text { Process flow } \\
\text { diagram, process } \\
\text { performance } \\
\text { parameter } \\
\text { models. }\end{array}$ \\
\hline $\begin{array}{l}\text { Examples of } \\
\text { decision } \\
\text { variables }\end{array}$ & $\begin{array}{l}\text { Level of product } \\
\text { attributes, price. }\end{array}$ & $\begin{array}{l}\text { Structure of the } \\
\text { product } \\
\text { development team, } \\
\text { incentives. }\end{array}$ & $\begin{array}{l}\text { Size of the } \\
\text { product, form, } \\
\text { configuration, } \\
\text { function, } \\
\text { dimensions. }\end{array}$ & $\begin{array}{l}\text { Sequence of the } \\
\text { development of } \\
\text { the process and } \\
\text { schedule; point } \\
\text { of differentiation } \\
\text { in the production } \\
\text { process. }\end{array}$ \\
\hline $\begin{array}{l}\text { Critical } \\
\text { success } \\
\text { factors }\end{array}$ & $\begin{array}{l}\text { Product } \\
\text { positioning, } \\
\text { pricing, } \\
\text { identifying and } \\
\text { meeting clients' } \\
\text { needs. }\end{array}$ & $\begin{array}{l}\text { Organizational } \\
\text { alignment, team } \\
\text { characteristics }\end{array}$ & $\begin{array}{l}\text { Creative concept, } \\
\text { configuration, } \\
\text { performance } \\
\text { optimization }\end{array}$ & $\begin{array}{l}\text { Suppliers, } \\
\text { selection of } \\
\text { materials, } \\
\text { production } \\
\text { sequence design, } \\
\text { project } \\
\text { management. }\end{array}$ \\
\hline
\end{tabular}

\section{Chart 2: Comparison of the perspectives of the Marketing, Organizations, Engineering and Operations academic communities}

Source: Krishnan and Ulrich (2001).

Based on a review of literature, Krishnan and Ulrich (2001) also presented a number of decisions that must be taken within a new product development process. These decisions are grouped into four categories: concept development, product design, supply chain design, and production process (Chart 3).

\begin{tabular}{|c|c|c|c|c|}
\hline \multirow{3}{*}{ 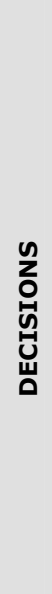 } & $\begin{array}{c}\text { CONCEPT } \\
\text { DEVELOPMENT }\end{array}$ & PRODUCT DESIGN & SUPPLY CHAIN DESIGN & $\begin{array}{l}\text { PRODUCTION } \\
\text { RAMP-UP AND } \\
\text { LAUNCHING }\end{array}$ \\
\hline & $\begin{array}{l}\text { What are the } \\
\text { target values of } \\
\text { the product's } \\
\text { attributes, } \\
\text { including price? }\end{array}$ & $\begin{array}{l}\text { What are the values of } \\
\text { the key parameters of } \\
\text { the project? }\end{array}$ & $\begin{array}{l}\text { Which components will be } \\
\text { designed and which will be } \\
\text { selected? Who will design the } \\
\text { components? }\end{array}$ & $\begin{array}{l}\text { What is the } \\
\text { market test } \\
\text { and launch } \\
\text { plan? }\end{array}$ \\
\hline & $\begin{array}{l}\text { What is the } \\
\text { product's core } \\
\text { concept? }\end{array}$ & $\begin{array}{l}\text { What is the } \\
\text { configuration of the } \\
\text { components and what } \\
\text { are the relations prior } \\
\text { to the assembly line? }\end{array}$ & $\begin{array}{l}\text { Who will produce the } \\
\text { components and make the } \\
\text { product's production line? }\end{array}$ & $\begin{array}{l}\text { What is the } \\
\text { plan for the } \\
\text { production } \\
\text { ramp-up? }\end{array}$ \\
\hline
\end{tabular}


Continuation

\begin{tabular}{|c|c|c|c|c|}
\hline \multirow{5}{*}{ 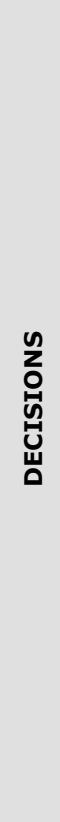 } & $\begin{array}{l}\text { CONCEPT } \\
\text { DEVELOPMENT }\end{array}$ & PRODUCT DESIGN & SUPPLY CHAIN DESIGN & $\begin{array}{l}\text { PRODUCTION } \\
\text { RAMP-UP AND } \\
\text { LAUNCHING }\end{array}$ \\
\hline & $\begin{array}{l}\text { What is the } \\
\text { architecture of } \\
\text { the product? }\end{array}$ & $\begin{array}{l}\text { What is the detailed } \\
\text { design of the } \\
\text { components, } \\
\text { including materials } \\
\text { and process } \\
\text { selection? }\end{array}$ & $\begin{array}{l}\text { What is the physical } \\
\text { configuration of the supply } \\
\text { chain, including the location } \\
\text { of the decoupling point? }\end{array}$ & \\
\hline & $\begin{array}{l}\text { Which product } \\
\text { variations will be } \\
\text { offered? }\end{array}$ & & $\begin{array}{l}\text { What kind of process will be } \\
\text { used to produce the product? }\end{array}$ & \\
\hline & $\begin{array}{l}\text { Which } \\
\text { components will } \\
\text { the product } \\
\text { variations share? }\end{array}$ & & $\begin{array}{l}\text { Who will develop and provide } \\
\text { the process and equipment } \\
\text { technologies? }\end{array}$ & \\
\hline & $\begin{array}{l}\text { What will be the } \\
\text { product's general } \\
\text { physical form and } \\
\text { industrial design? }\end{array}$ & & & \\
\hline
\end{tabular}

\section{Chart 3: Product development decisions within a project.}

Source: Krishnan and Ulrich (2001).

\section{DEVELOPMENT OF POPULAR PRODUCTS}

Giovinazzo (2003) defines popular products as those positioned predominantly for the C, D and E income classes. The income-effect of these products is negative, i.e., income growth results in consumers replacing such products or brands by more upscale or elaborate ones. Conversely, a "normal" product or brand has a positive income-effect, in that an income increase results in its increased consumption.

Nascimento, Yu and Sobral (2005) state that a popular product is not necessarily the cheapest product in its category, because, even though price is important, it is not the only prerequisite. They point out that the popular product concept must:

a) Prioritize the needs of low-income consumers; in Brazil, this means families earning less than ten minimum salaries or families classified as belonging to classes C, D or E. However, certain situations may arise in which higher-income consumers become interested in buying such products; 
b) Offer quality at a low price, the two fundamental prerequisites for this market; however, a popular product is not necessarily the cheapest in its category; instead, it may offer terms that make it easier for its target consumers to buy it, such as credit, points of sale, fulfilling consumer needs, etc.

c) Have the right product life-cycle attributes: reliability regarding its rate of failure and the materials used in the product; human factors, such as being user-friendly and convenient, providing the appropriate level of control complexity, and avoiding potential hazards; easy maintenance; easy installation and installation requirements; reasonable delivery time and easy access. Therefore, a popular product must meet the needs of the needier population during its entire life cycle.

Giovinazzo (2003) identified the strategic profile of companies that focus on the popular market and the characteristics of their strategic dimensions. Table 4 indicates that they appear to have a clearly defined profile.

\begin{tabular}{l|l|}
\hline \multicolumn{1}{|c|}{ IMPORTANT CRITICAL VARIABLES } \\
\hline Price & $\begin{array}{l}\text { Most important variable for the strategies of companies that charge the } \\
\text { market's lowest prices, this factor being the major competitive component. }\end{array}$ \\
\hline Cost & $\begin{array}{l}\text { Low costs are these companies' leading strategic component. They invest in } \\
\text { cost-reducing facilities, equipment and methods, to incur in the lowest } \\
\text { possible costs; charge low prices is the main strategic factor. }\end{array}$ \\
\hline $\begin{array}{l}\text { Distribution and } \\
\text { differentiation } \\
\text { channel }\end{array}$ & $\begin{array}{l}\text { Although competitiveness stems from low prices, these companies want } \\
\text { their brand to have a certain degree of differentiation. However, the chief } \\
\text { way of achieving this differentiation is not by means of advertising, i.e., by } \\
\text { means of investments in the development of the brand's identification, but } \\
\text { rather by means of promotions and support of their products' distribution } \\
\text { channels and points of sale. }\end{array}$ \\
\hline $\begin{array}{l}\text { Quality } \\
\text { Client Services }\end{array}$ & $\begin{array}{l}\text { The company seeks to meet all the requirements in terms of raw materials, } \\
\text { specifications, compliance with tolerances, etc. }\end{array}$ \\
\hline $\begin{array}{l}\text { Specialization/ } \\
\text { products } \\
\text { diversification } \\
\text { and } \\
\text { segmentation }\end{array}$ & \begin{tabular}{l} 
Concerning the extent to which the company makes an effort to expand the \\
product lines or market segments, companies target the popular market \\
focus less on products or market segments than those that focus on the A \\
and B classes; these companies operate with a broader range of products \\
and segments. \\
\hline only the basic services.
\end{tabular} \\
\hline
\end{tabular}


Continuation

\begin{tabular}{|l|l|}
\hline \multicolumn{2}{|c|}{ LESS IMPORTANT VARIABLES } \\
\hline $\begin{array}{l}\text { Brand } \\
\text { identification and } \\
\text { advertising }\end{array}$ & $\begin{array}{l}\text { The company does not differentiate its brand as the leading competitive } \\
\text { factor via advertising, sales force, packaging or other investments. These } \\
\text { companies seek differentiation via distribution channels, unlike the } \\
\text { companies that target the A and B classes, which pursue brand } \\
\text { identification by the end consumer. }\end{array}$ \\
\hline Technology & $\begin{array}{l}\text { Concerning the extent to which the company seeks to achieve technological } \\
\text { leadership in its sector, as opposed to maintaining imitative product and } \\
\text { process technologies, the companies that target popular markets do not } \\
\text { conduct research activities and resort to existing, well-known technologies. }\end{array}$ \\
\hline
\end{tabular}

\section{Chart 4: Critical strategic variables of companies focused on the low- income market.}

Source: Giovinazzo (2003).

Research projects for the development of popular products have looked for answers to the issues mentioned in the study by Krishnan and Ulrich (2001) on the development process of new products.

Wright $(1993,1994)$ states that popular products should comply with the following guidelines: simplicity, with no exaggerated pursuit of market differentiation; manufacturing economies of scale, enabling the standardization of components, which may be developed and produced cooperatively by companies from the given sector; extensive standardization of parts, components and durables, which must be amenable to corrective maintenance as opposed to disposables; longer life cycles, which, coupled with durability, make it feasible to provide credit to low-income consumers and that allow for the creation of a secondary market for durable goods; environment-friendliness, which reduces the consumption of non-renewable resources and facilitates recycling; and selective use of modern technology.

Nascimento and Yu (2003) highlight certain popular innovation strategies: low unit cost and large-scale production to reduce unit costs; low-cost physical distribution and speedy delivery; preference for small retailers as the product points of sale, thus circumventing the strong bargaining power of the major retail chains; purchase terms, such as affordable pricing, small installments and no collateral (these are among the most important criteria); attention to the needs and preferences of this target audience; ability to capture changes in popular preferences; and, above all, the rapid development and launch of products that meet demand. 
Prahalad (2005) proposes 12 innovation principles for the markets at the base of the pyramid: price performance; hybrid solutions with high technology and limited infrastructure; economies of scale through solutions that can be adapted to different markets; reduction of usable resources and use of environment-friendly products; identification of functionalities compatible with the market; process innovation; de-specialization of work, adapting it to the skills available; education of clients on how to use the products; design compatible with hostile infrastructure; design with friendly product/client interface, taking cultural differences into account; distribution systems that provide access to clients; and focus on the system's platform/architecture.

Wright (1993, 1994), Nascimento and You (2003), and Prahalad (2005) mention certain common features of the supplying of products for low-income consumers, summarized in Table 6.

\begin{tabular}{|c|c|c|c|}
\hline & WRIGHT $(1993,1994)$ & NASCIMENTO AND Yu (2003) & Prahalad (2005) \\
\hline \multirow{3}{*}{ 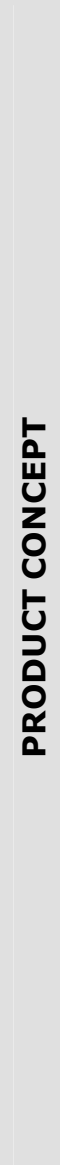 } & $\begin{array}{l}\text { - Simple product, no } \\
\text { exaggeration in the } \\
\text { pursuit of marketing } \\
\text { differentiation. }\end{array}$ & $\begin{array}{l}\text { - It is vital to pay attention } \\
\text { to the preferences and } \\
\text { needs of this target } \\
\text { audience. }\end{array}$ & $\begin{array}{l}\text { - } \text { Identification of } \\
\text { functionalities } \\
\text { compatible with the } \\
\text { market. } \\
\text { - } \text { Client/product interface } \\
\text { design, taking cultural } \\
\text { differences into account. }\end{array}$ \\
\hline & $\begin{array}{l}\text { - Product geared to } \\
\text { economies of scale in } \\
\text { terms of manufacturing, } \\
\text { allowing for the } \\
\text { standardization of } \\
\text { components that can be } \\
\text { developed and produced } \\
\text { in cooperatively by } \\
\text { companies from the } \\
\text { sector. }\end{array}$ & $\begin{array}{l}\text { - Low unit cost and large- } \\
\text { scale production. } \\
\text { - } \text { Get as much advantage } \\
\text { as possible from scale and } \\
\text { efficiency to reduce unit } \\
\text { costs. }\end{array}$ & $\begin{array}{l}\text { - Gain of scale with } \\
\text { solutions that can be } \\
\text { adapted to different } \\
\text { markets. }\end{array}$ \\
\hline & $\begin{array}{l}\text { - Longer life cycles that, } \\
\text { coupled with durability, } \\
\text { make it viable to provide } \\
\text { credit to lower-income } \\
\text { consumers, resulting in } \\
\text { the creation of a } \\
\text { secondary market for } \\
\text { durable goods. }\end{array}$ & 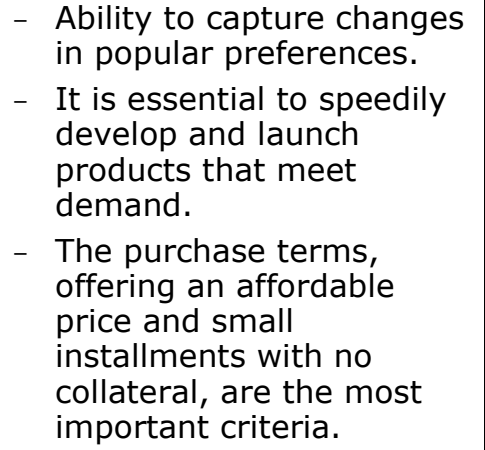 & $\begin{array}{l}\text { - Price performance. } \\
\text { - Focus on the system's } \\
\text { platform/architecture. }\end{array}$ \\
\hline
\end{tabular}


Continuation

\begin{tabular}{|c|c|c|c|}
\hline & WRIGHT $(1993,1994)$ & NASCIMENTO AND Yu (2003) & Prahalad (2005) \\
\hline \multirow{2}{*}{ 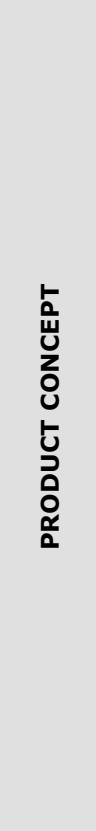 } & $\begin{array}{l}\text { - Product geared to } \\
\text { economies of scale in } \\
\text { terms of manufacturing, } \\
\text { allowing for the } \\
\text { standardization of } \\
\text { components that can be } \\
\text { developed and produced } \\
\text { in cooperatively by } \\
\text { companies from the } \\
\text { sector. }\end{array}$ & $\begin{array}{l}\text { - Low unit cost and large- } \\
\text { scale production. } \\
\text { - Get as much advantage } \\
\text { as possible from scale } \\
\text { and efficiency to reduce } \\
\text { unit costs. }\end{array}$ & $\begin{array}{l}\text { - Gain of scale with } \\
\text { solutions that can be } \\
\text { adapted to different } \\
\text { markets. }\end{array}$ \\
\hline & $\begin{array}{l}\text { - Longer life cycles that, } \\
\text { coupled with durability, } \\
\text { make it viable to provide } \\
\text { credit to lower-income } \\
\text { consumers, resulting in } \\
\text { the creation of a } \\
\text { secondary market for } \\
\text { durable goods. }\end{array}$ & $\begin{array}{l}\text { - Ability to capture changes } \\
\text { in popular preferences. } \\
\text { - } \text { It is essential to speedily } \\
\text { develop and launch } \\
\text { products that meet } \\
\text { demand. } \\
\text { - The purchase terms, } \\
\text { offering an affordable } \\
\text { price and small } \\
\text { installments with no } \\
\text { collateral, are the most } \\
\text { important criteria. }\end{array}$ & $\begin{array}{l}\text { - Price performance. } \\
\text { - } \text { Focus on the system's } \\
\text { platform/architecture. }\end{array}$ \\
\hline 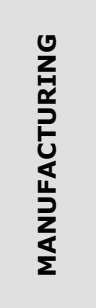 & $\begin{array}{l}\text { - Durable products with } \\
\text { high standardization of } \\
\text { parts and components, } \\
\text { that can be fixed if } \\
\text { needed (as opposed to } \\
\text { disposable products). } \\
\text { - Selective use of modern } \\
\text { technology. }\end{array}$ & & $\begin{array}{l}\text { - Process innovation. } \\
\text { - Hybrid solutions with high } \\
\text { technology and limited } \\
\text { infrastructure. }\end{array}$ \\
\hline 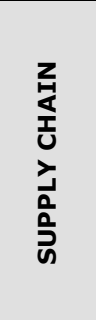 & & $\begin{array}{l}\text { - Preference for small } \\
\text { retailers as points of sale. } \\
\text { - } \text { Low cost distribution and } \\
\text { speedy delivery. } \\
\text { - } \text { Deliberate avoidance of } \\
\text { the major retail chains } \\
\text { because of their great } \\
\text { bargaining power. }\end{array}$ & $\begin{array}{l}\text { - Distribution systems that } \\
\text { provide access to clients }\end{array}$ \\
\hline 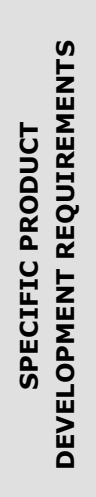 & $\begin{array}{l}\text { Environment-friendly } \\
\text { products, reducing the } \\
\text { consumption of non- } \\
\text { renewable resources and } \\
\text { facilitating recycling. }\end{array}$ & & $\begin{array}{l}\text { - Educate clients to teach } \\
\text { them how to use the } \\
\text { products. } \\
\text { - } \text { De-specialization of work, } \\
\text { adapting the work } \\
\text { required to the skills } \\
\text { available. } \\
\text { - Design compatible with a } \\
\text { hostile infrastructure. } \\
\text { - Reduction of resources } \\
\text { used in production and } \\
\text { use of ecologically correct } \\
\text { products. }\end{array}$ \\
\hline
\end{tabular}

Chart 5: Guidelines for the supply of products to popular markets

Source: adapted from Wright $(1993,1994)$, Nascimento and You (2003), and Prahalad (2005). 


\section{FINAL COMMENTS}

This paper aimed to retrieve the history of popular markets prospects and to identify the development trends for popular products.

Regarding the first objective, the work of Wright and Johnson (1984), were studied. Their scenarios predicted that Brazil would maintain the qualitative and quantitative progress of its social and economic development in forthcoming decades, which would be evidenced by income growth and more equitable income distribution, reflecting the values of a more egalitarian society.

Concerning the second objective, the research and development of popular products is still proceeding at full speed. Several functional perspectives are being used for the study of development trends, especially marketing, engineering and manufacturing.

The analysis of the research work conducted by different authors shows that the development of products for the base of the pyramid is an crossfunctional activity that calls for integrated solutions and challenges companies to align themselves with the several internal requirements of an unexplored market, on which there is very little information, given that scientific production about it is still in the finalization and publication phase.

\section{REFERENCES}

Clark, K. B. and Wheelwright, S. C. (1993). Managing New Product and Process Development. New York: Free Press.

Giovinazzo, R. A. (2003). Um estudo sobre o desempenho e a estratégia das empresas que atuam no mercado de bens populares no Brasil. Master's Degree Dissertation, FEA-USP (School of Economics, Business Administration and Accounting of the University of São Paulo), SP, Brazil.

Hammond, A.; Kramer, W. J.; Tran, J.; Katz, R. and Walker, C. (2007). The next four billion: market size and business strategy at the base of the pyramid. Washington, DC: World Resources Institute.

Instituto Brasileiro de Geografia e Estatística. (2006). Pesquisa Nacional de Amostra por Domicílios.

Instituto Brasileiro de Geografia e Estatística. (2003). Pesquisa de Orçamentos Familiares 2002-2003. 
Krishnan, V. and Ulrich, K. T. (January 2001). "Product development decisions a review of the literature." Management Science, 41 (1), 1-21.

Wright, J. T. C. (30 June 1994). "Bens populares, o plano e o futuro." O Estado de São Paulo.

Wright, J. T. C. (22 March 1993). "De volta ao fusca ou uma nova política industrial?" O Estado de São Paulo.

Wright, J. T. C. and Johnson, B. B. (1984). Cenários de telecomunicações do ano 2000 [Final Report]. Programa de Estudos do Futuro [Future Studies Program].

Nascimento, P. T.; Yu. A. and Sobral, M. C. (October 2005). "Estratégias de Negócios e Inovação em Mercados de Produtos Populares." Anais Eletrônicos do Seminário de Gestão Tecnológica, 11, Salvador, Brazil.

Nascimento, P. T.; Yu, A. (2003). "Estratégias de Inovação para Produtos de Consumo Popular." Anais do Seminário em Administração [CD ROM], 6, São Paulo: FEA-USP (School of Economics, Business Administration and Accounting of the University of São Paulo).

Barros, R. P. de; Carvalho, M.; Franco, S. and Mendonça, R. A queda recente da desigualdade de renda no Brasil. Retrieved in August 2008, from http://www.ipea.gov.br/sites/000/2/livros/desigualdaderendanobrasil/Cap_02 _AQuedaRecente.pdf $>$.

Prahalad, C. K. (2005). A riqueza na base da pirâmide: como erradicar a pobreza com o lucro. Porto Alegre, Bookman.

Slack, N.; Chambers, S. and Johnston, R. (2007). Administração da produção. São Paulo: Atlas.

Takahashi, S. and Takahashi, V. P. (2007). Gestão de Inovação de Produtos estratégia, processo, organização e conhecimento. Rio de Janeiro: Campus. 